\title{
The effect of rapid social changes during post-communist transition on perceptions of the human - wolf relationships in Macedonia and Kyrgyzstan
}

\author{
Nicolas Lescureux ${ }^{*}$ and John D C Linnell
}

* Correspondence:

nicolas.lescureux@nina.no

Norwegian Institute for Nature Research, Sluppen, P.O. Box 5685, Trondheim 7485, Norway

\begin{abstract}
The relationship between humans and wolves is often associated with conflicts strongly linked with livestock breeding activities. However, as conflicts are often more intense than expected considering the magnitude of their economic impact, some authors have suggested that these conflicts are disconnected from reality and are mainly due to persistence of negative perceptions from previous times. To the contrary, we suggest that local people's perceptions are often linked to wolf behaviour through direct observations and interactions. We conducted ethnological investigations on human-wolf relationships in countries belonging to former USSR (Kyrgyzstan) and former Yugoslavia (Republic of Macedonia), subjected to rapid social changes impacting both livestock husbandry and hunting practices. Our studies revealed that changes in hunting and husbandry practices have led to modifications in the socio-environmental context and to the nature of wolf-human interactions. These changes have resulted in an increased vulnerability of local people to wolf damage and a concomitant reduced acceptance for wolves. All these changes contribute to changes in the perception of the wolf and to an increase in the perception of conflicts, even in countries where humans and wolves have continuously coexisted. Our study shows the dynamic nature of human-wolf relationships, the necessity to understand the broader socio-economical context in human-wildlife conflicts, and the challenge pastoralists are facing in a changing world.
\end{abstract}

Keywords: Macedonia, Kyrgyzstan, Livestock-breeding, Hunting, Transition, Humanwolf conflicts, Interactions

\section{Background}

The carnivorous diet and need for large living areas of large carnivores has led to an age-old competition with humans for space and food, thereby generating a range of economic and social conflicts (Treves and Karanth 2003). The most common dimension of conflict between humans and large carnivores - especially wolves - remains livestock depredation, and this conflict has been responsible for motivating the past reduction in the number and distribution of large carnivores on a worldwide level (Mech 1995, Breitenmoser 1998, Kaczensky 1999). Among large carnivores, wolves appear as 
one of the most conflictful species wherever they occur and overlap with herding activities, especially with sheep breeding. Nowadays, in many countries, either rural land abandonment or conservation legislation or both of them are leading to the recovery of large carnivores in multiple-use landscapes (Linnell et al. 2001, Falcucci et al. 2007, Linnell et al. 2009) and accordingly many conflicts are currently increasing in several countries (Mech 1970, Fritts et al. 1997, Bangs et al. 1998, Breitenmoser 1998, Treves and Karanth 2003).

Economic impacts appear to be generally low at national levels. A review of large carnivore impact on livestock in Central Europe showed that in most areas less than 1\% of livestock is taken by large carnivores (Kaczensky 1999). Therefore, considering that present day economic impacts and risks to human safety (Moore 1994, Røskaft et al. 2003, Røskaft et al. 2007) are not sufficient to explain the intensity of the negative perceptions and social conflicts currently surrounding large carnivores, some authors have proposed that conflicts with large carnivores reflect the long-term persistence of negative perceptions from earlier times (Clark et al. 1996a, 1996b, Kellert et al. 1996, Lohr et al. 1996, Fritts et al. 2003).

However, it is also recognized that economic impacts can be very intense on a local level (Kaczensky 1999) and it appears that in some countries they are far more important (e.g. in Romania, cf. Mertens and Promberger 2001), and this may also be influenced by the presence or absence of compensation systems. In addition, several studies show that risks to human safety, even if close to zero in the modern occidental world, used to exist in Europe in the past and still exist in some developing countries (Rajpurohit 1999, Comincini et al. 2002, Linnell et al. 2003, Løe and Røskaft 2004, Moriceau 2007). Therefore, even if it is possible that some negative perceptions are inherited from earlier time, it also appears that they could find their root in actual human - wolf relationships and their real negative aspects. In addition, observing that tolerance to large carnivores is lower where the tradition of living together with them has been lost, Boitani suggested that prolonged sympatry can lead to a form of coexistence where compromises are made by both species and conflicts are not perceived as being so intense (Boitani 1992, 1995). This more dynamic and interactive vision is partly supported by ecological studies revealing the impact human activities can have on wolf behaviour and ecology (Vilà et al. 1995, Ciucci et al. 1997, Theuerkauf 2003, Theuerkauf et al. 2003a, 2003b) even though this impact has to be assessed through more generalized and standardized studies (Theuerkauf 2009). Concerning the impact wolves can have on humans, it has been addressed through studies about wolves in history and mythology (see e.g. Lopez 1978, Coleman 2004, Walker 2005), the study of symbolism in our modern perceptions of wolves (Bobbé 1993b, Bobbé 1993a, Bobbé 2003) and sociological analysis of wolf impacts on human society (Brox 2000, Mauz 2005, Skogen et al. 2008, Doré 2010). All these studies clearly show the impact wolves can have on humans at different levels but they are rarely connected with studies on the human impact on wolf behaviour and ecology, apart from some historical studies using historical data on both humans and on wolves (Moriceau 2007, Alleau 2010). Therefore they rarely shed light on the processes through which the human - wolf relationships are constructed.

The relatively recent integration of animals into social sciences through the recognition of their status as actors and active agents able to influence human social life 
(Descola and Pálsson 1996, Ingold 1996, Latour 1996, Ingold 2000, Haraway 2003, Brunois 2005a, 2005b, Descola 2005) has permitted the development of new interdisciplinary approaches to human - large carnivore relationships spanning both scientific and local knowledge (Lescureux 2006). These new approaches reveal the influence large carnivore behaviour can have on human perceptions and activities, and also provide insights into the interactive and dynamic character of human - wolf relationships (Lescureux 2006, Lescureux and Linnell 2010).

If the wolf - human relationship is so dynamic, social, economic and political transitions in human society should also result in changes to the human - wolf relationship. The rapid social changes like the ones which have occurred in most eastern European and central Asian countries at the beginning of the 1990's provide an opportunity to assess this dynamic and interactive nature of human - wolf relationships. Indeed, our hypothesis is that these changes potentially affected the human - wolf relationships in two manners. Firstly, these social changes have a direct impact on wolf ecology and behaviour through the changes in human hunting (of both wolves and their prey) and livestock husbandry practices. Secondly, rapid social changes create a new ecological and socio-economical context in which the human perception of wolves and their place in this context will be affected, all the more as the ecology and behaviour of this animal change. In turn, the changes in human perceptions of wolves will influence wolf hunting and livestock husbandry practices. Given the complexity of these processes, the comparison between two different countries which both underwent rapid social changes but through different processes allows us to explore how two different contexts have influenced the way the human - wolf relationship changed along with the rapid social changes. In addition, this comparison offers the possibility to better understand the origins of human - wolf conflicts in different contexts and to disentangle the different components (material, symbolic, relational) of these conflicts, which is a necessary step to be able to address them adequately.

\section{Study areas}

We conducted research in two countries where rapid social changes occurred after the fall of the USSR and the fall of Yugoslavia. These were respectively the Republic of Kyrgyzstan where ethnographic surveys were made between 2003 and 2006, and the Republic of Macedonia where surveys were made between 2007 and 2010.

Kyrgyzstan and Macedonia are both mountainous countries, but there are some differences between these countries. Kyrgyzstan is larger than Macedonia and has a lower population density, which can be explained by the topographic conditions and overall low productivity. Indeed, more than $70 \%$ of the country is above $2000 \mathrm{~m}$ high and the highest peak reaches to more than $7000 \mathrm{~m}$. The two countries are well suited for sheep husbandry, as permanent pastures constitute $47 \%$ of Kyrgyzstan's total land area and 25\% of Macedonia's total land area. The landscape of Kyrgyzstan is an open one, as forest only covers $5 \%$ of the country. This open landscape favours mutual observations between humans and wolves. This is not the case in Macedonia where $37 \%$ of the total land area is covered by forest. The wolf is a hunted species in both countries, without limits on the hunting season or quota. Rough estimations give a 
population of 4000 to 6000 wolves in Kyrgyzstan and 800 to 1000 wolves in Macedonia (Boitani 2003, Salvatori and Linnell 2005).

In Kyrgyzstan, the study was conducted in two different areas (see Figure 1). The first one consisted of several villages around At-Bashy in Naryn region. These villages are at an elevation of around 2,500 m.a.s.l, and the main activity is livestock breeding, with a few cultivated areas, used mainly for onions and potatoes. The second one was focused on villages around Bokonbaevo in the Issyk-Kul region. These villages are situated along the Issyk-Kul Lake, at an altitude of around 1,600 m.a.s.l. and enjoy a milder climate allowing agricultural activities other than livestock breeding. Some interviews were also conducted in high pastures away from villages. As for the rest of the country, these areas are only sparsely forested. They mainly consist of agricultural areas with open fields and meadows in the valley bottoms with some shrubs, mainly along rivers. The landscape quickly shifts to alpine meadows with increasing altitude. Despite the departure of numerous young people to the capital, the study villages had not become depopulated, and had even experienced a slightly positive growth due to a high birth-rate. Wolves have been continuously present in the country for centuries and are subject to bounty hunting.

In Macedonia, the study was conducted in the Polog and Yugozapaden regions (municipalities of Tetovo, Gostivar and Mavrovo-Rostushe, see Figure 1). The area is predominantly rural, consisting of small towns and agricultural areas in the valley bottoms, with forested slopes, and alpine meadows at higher altitudes. The forests are widely used for hunting and forestry, and the alpine meadows are used by both transhumant and resident shepherds from May to October. Villages are scattered throughout the landscape, and have suffered dramatic and long term declines of the human population during recent decades, accelerating in recent years. Bears, wolves, and lynx have been continuously present during recent centuries in these regions of western Macedonia's mountains

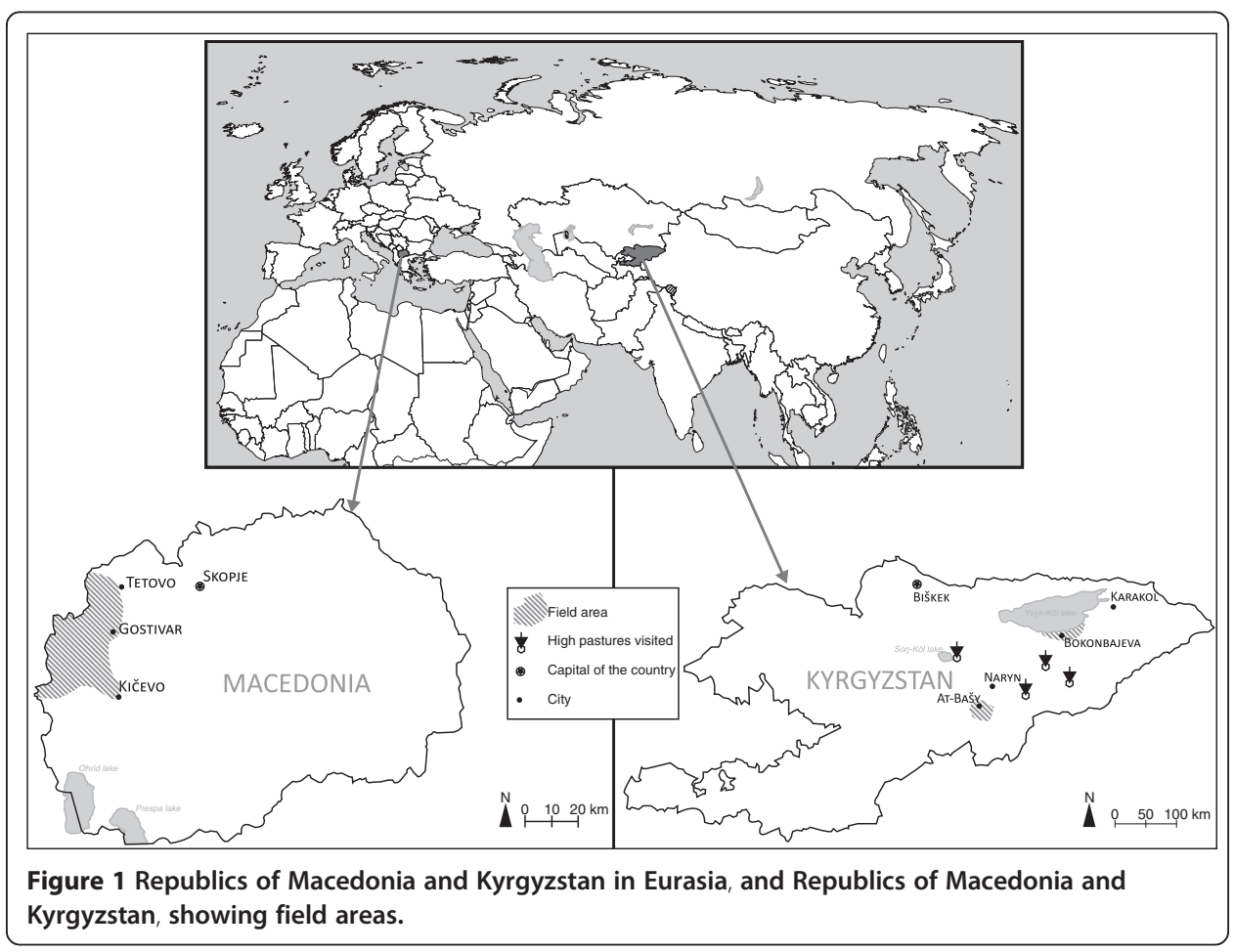


(Servheen et al. 1998, Salvatori and Linnell 2005, Ivanov et al. 2008). Both ethnic Albanian and ethnic Macedonians were interviewed. The population of wolves is still large and well connected with those in neighbouring countries.

\section{Methods}

This study is based on results from ten months of ethnological survey conducted between 2003 and 2007 in Kyrgyzstan and six months of ethnological survey in Macedonia between 2007 and 2011. In both countries we focused on two groups that appeared to be the most knowledgeable about, and the most involved in conflicts, with wolves: livestock breeders and hunters. In Kyrgyzstan our survey was mainly focused on a few villages since livestock breeders are still numerous, allowing us to make some participant observations, living with a family in the village for several weeks and participating in some activities. However in Macedonia, there were too few livestock breeders and hunters per village. Therefore, we had to visit 33 villages to obtain an acceptable number of informants and participant observation was not possible given the limited time.

In both countries we used semi-structured in-depth interviews to explore local knowledge, perceptions and practices linked to the wolf. This method was chosen because 1) we wanted to obtain informants' categories with as little influence as possible from the ethnographer, and 2) we were focused on a particular topic, i.e. the human - wolf relationships. The use of an interview guide ensured that we addressed each subtopic with informants but we freely covered other subtopics when they took interesting directions (Huntington 2000). Sometimes we were not able to address some questions because of lack of time, misunderstanding, or a lack of will from the informant to answer the particular question.

Even if focused on local knowledge about wolf behaviour and ecology, the interview guide was containing questions concerning 1) daily activities, especially those linked with livestock breeding, and 2) local categorization of animals, space, and landscape in order to see if there is a distinction between nature and human, wild and domestic, and any place considered as wilderness, and where different animals are categorized inside this division of space. We were also particularly interested in reports of interactions with wolves in different contexts.

Interviews were conducted by the ethnographer (NL) accompanied by a native Kyrgyz translator in Kyrgyzstan and by native Albanian or Macedonian speakers in Macedonia, entirely recorded, and later transcribed and translated. While in Kyrgyzstan the interviews were translated with the help of the accompanying translator, in Macedonia we tended to use a different translator for the field and for the translation, thus allowing a crosschecking of the interviews.

A typical interview lasted for one hour or more and they were conducted in cafes, in private homes or directly in the field. In Kyrgyzstan, a total of 77 people were interviewed, mainly livestock breeders who were often hunters too, and also some folk medicine practitioners. In Macedonia, a total of 97 people were interviewed, including 57 livestock breeders, and 39 hunters. When historical resources were available, we also made some investigations into the development of livestock breeding and hunting activities and we also went through various statistical, government and NGO reports concerning livestock breeding in the two countries. 


\section{Results and discussion}

The first section of results largely summarises the changes that have occurred during post-communist transitions as described in public records and statistics, while the second part concerns the ways rural inhabitants, especially livestock breeders, perceive this change and the ways it has influenced their relationship with wolves.

\section{A transition process affecting the context of human - wolf relationships A general collapse of sheep breeding activities}

Our investigations highlighted that the institutional and economic crisis following the collapse of the USSR and Yugoslavia had a strong impact on livestock breeding and hunting activities which were mainly dependent on the State before the collapse of USSR and Yugoslavia. Sheep breeding was the agricultural activity most affected by this crisis. Between 1992 and 2006, the number of sheep was halved in Macedonia and reduced to a third in Kyrgyzstan.

In Kyrgyzstan, the transition to a market economy was quite abrupt as in many former Soviet Republics in Central Asia (cf. Dear et al. 2012). Before the transition, all of the land was state property and most of the sheep (77\%) were owned by the State and collective farms (Van Veen 1995). At the beginning of the transition process, many flocks were sold to pay collective farm debts in a context of high inflation, or sent to slaughter houses by unscrupulous chiefs or privatized on a patronage network basis (Jacquesson 2004). The number of sheep reached its minimum in 2004 and started to slowly increase from that year (FAOSTAT 2012). The situation was somewhat different in Macedonia, a place with a long tradition of pastoralism (Hadjigeorgiou 2011), as peasants in Yugoslavia had the choice to become private producers already in the 1950's (Boyd 1987). Therefore, even before transition, $90 \%$ of the sheep were privately owned even if State or collective farms (Agro-Kombinat) had large flocks ranging between 1,000 and 25,000 sheep (MAFWE 2003). The first reason for a post-communist decrease in sheep in Macedonia was the EU ban on the import of lamb meat from the country following the outbreak of foot-and-mouth disease in 1996 (Dimitrievski and Ericson 2010). Subsequently, the low prices of meat, milk, and wool combined with the high prices of fodder and concentrate feed, as well as the rising of costs of labour pushed the sheep breeders to reduce the size of their flocks (Dimitrievski and Ericson 2010).

\section{Contrasting trajectories of rural communities}

Although Kyrgyzstan and Macedonia are both undergoing changes in the dynamics of their rural populations, its nature and intensity are quite different in the two countries. In Yugoslavia, an economic and cultural policy of centralization as well as an accelerated industrialization starting in the 1960's led to an exodus from the countryside to towns and a concomitant decrease in the agricultural sector (Hadživuković 1989). Shepherds also went to work in other countries, like in Italy, where their knowledge is appreciated (Pardini and Nori 2011). At the time of the Russian revolution, Kyrgyzstan was mainly occupied by nomadic livestock breeders and Russian colonists. After the restitution of colonists' land to the Kyrgyz people in 1921-1922 a process of collectivisation and the creation of kolkhozes was initiated from 1925 to 1932, which was accompanied by the settlement of the nomads (Jacquesson 2004). As the Kyrgyz economy remained focused on livestock breeding, there was no massive rural exodus like in Yugoslavia. Moreover, 
even if the proportion of rural population in Kyrgyzstan is slightly decreasing, the rural population growth rate remains positive until now while it started to be negative as early as the 1960's in Yugoslavia. As a consequence, the proportion of the population living in rural areas in Macedonia dropped from 76.6\% in 1950 to 27.7\% in 2010 (FAOSTAT 2012) while in Kyrgyzstan it only decreased from $73.5 \%$ to $63.4 \%$ in the same period (FAOSTAT 2012), implying that Kyrgyzstan remains a rural country while Macedonia became mainly urban from the 1970's. In Macedonia, there is a strong rural abandonment, a continuous decrease of the rural population (with a rural population growth rate of $-2.2 \%$ during the 2005-2010 period, cf. FAOSTAT 2012), and a strong decline in the rural way of life, with a feeling of lack of respect for rural people and livestock breeders.

\section{Changes in hunting pressure on wolves}

The post-communist upheaval in the USSR and Yugoslavia also had an impact on hunting activities. It is highly probable that this impact was particularly strong in Kyrgyzstan where hunting was partly an economic activity providing meat, fat, and fur. Each kolkhoz used to have its professional hunters, and shepherds were also equipped with rifles. Looking at the general picture in the USSR, it is obvious that wolf hunting was highly organized at the State level and subsidised (Bibikov 1973, 1980, Bibikov et al. 1983). Wolves were considered as pest animals and trapped, captured in dens, poisoned and eventually hunted from planes or helicopters in open areas. The economic and logistical means supporting this intensive wolf hunting were no longer available after the collapse of the USSR. In Kyrgyzstan, the membership of the hunting association dramatically decreased from 25,900 in 1990 to 8,617 in 2002 as a consequence of Russian emigration from Kyrgyzstan. This decrease could be compensated by an increase in poaching from non-registered hunters, but it appears that the possession of small arms (legal or illegal) in the country is quite low (MacFarlane et al. 2004). As a consequence, it is highly probable that the hunting pressure on wolves really decreased after the independence of Kyrgyzstan, as in other former Soviet countries (e.g. Belarus, cf. Sidorovich et al. 2003).

On the other hand, the decrease in livestock numbers could have had an impact on wolf populations, even if the scarce data available on wolf diet in Kyrgyzstan doesn't show a high proportion of domestic animals (ca. 15\% in the Central Tian Shan according to Vyrypajev and Vorobjev 1983). The level of poaching and its impact on wild ungulates and marmots (Marmota baibacina, M. caudate, M. menzbieri), which are the wolf's main wild prey in Kyrgyzstan, remains unknown. It certainly increased for highly valuable species like snow leopard (Uncia uncia) and probably also for argali sheep (Ovis ammon) and ibex (Capra ibex) which can provide meat and valuable trophies (Koshkarev 1994).

As for livestock breeding, the impact of the transition process on the organization of hunting was probably less dramatic in former Yugoslavia than in Kyrgyzstan. Macedonia is divided into 249 hunting grounds and apart from the State hunting grounds, an open competition was held in 2002 to award concessions to the highest bidders (Petkovski et al. 2003). Users of the hunting ground have to pay for the management plan as well as an annual fee of $20 \%$ of the estimated value of the game present within the hunting ground (Petkovski et al. 2003). According to Petkovski et al. 2003, hunters are largely dissatisfied since they have to pay for expensive management plans when at the same time the legal 
system doesn't ensure the punishment of poachers. Therefore, many users are not paying their membership fees and poaching is considerably higher than before independence as a result of the lack of an organised game warden service. A report from the Ministry of Environment (Ministry of Environment and Physical Planning 2003) also bemoans the fact that despite the existence of hunting management plans and a Public Enterprise for Game Wardens and Hunting Inspections, poaching remains at a high level. Concerning the wolf, the number of wolves reported as being killed has slowly increased since the 1960's and although there are no statistics for the transition period 1988-1992, it jumped from 200 wolves killed in 1987 to 460 in 1994, showing that hunting pressure on wolves didn't decrease, except maybe during the 1988-1992 period. Current harvests (2008-2010) have been between 108 and 188 wolves killed per year. Nowadays, wolves are classified as pests in both countries and there is a bounty for killed wolves. However, wolf hunting requires good hunting skills and time. In Macedonia, wolves are mainly killed by chance when hunting other animals while in Kyrgyzstan they are still actively hunted by knowledgeable hunters even though the bounty is not really a motivation since it is not always paid because of corruption.

\section{Redefining the place of the wolf in a changing socio-economic and environmental context}

Although both Kyrgyzstan and Macedonia went through radical transition processes, these had different influences on the relationships between livestock breeders and wolves. In Kyrgyzstan, the human population remains predominantly rural and livestock breeding remains one of the main activities in the country, and wolves are considered as one of the main threats for livestock breeders. In Macedonia, rural abandonment has been dramatic and livestock breeders are becoming increasingly rare. They feel isolated and ignored by the State and they have to face economic difficulties which are endangering this activity. We illustrate these contrasting development paths through a series of narratives that emerged from our fieldwork.

\section{Wolves as one of the main threats to the capital of Kyrgyz villagers}

As we saw in the first part, Kyrgyzstan had to face a hard and dramatic transition process. Many people complained about the economic situation and all the advantages they lost with the collapse of Soviet Union, especially the social security brought by the State and the job security they had being employees of kolkhoz or sovkhoz (cf. Anderson and Pomfret 2000 for economic analysis of Kyrgyz households during Transition Process).

However, despite these changes, livestock breeding remains one of the main activities in the country, accounting for $44 \%$ of the total agricultural output in 2004 (World Bank 2005). In addition, with the loss of social security and as a consequence of very low pensions and salaries, livestock became a vital form of capital and most villagers have a few sheep, one or two cows and sometimes a few horses. Cows are mainly milked for family use, and mares are milked for producing fermented mare's milk (kymyz), a highly valued drink in Kyrgyz society. Other animals are mainly kept as a capital which can be sold in case of important expenditures (school and university fees, hospitalization, etc.). Under these conditions, villagers are always trying to increase the size of their flock, since it means increasing their capital (cf. Liechti 2012 too for the change in the meaning of livestock). As a consequence, when a wolf attacks livestock, it is not only threatening an 
ongoing commercial activity which produces income, but also villagers' capital. Therefore, even if taking into account the bias brought by the fact the surveys were focused on wolves, it appears that these animals are considered as one of the main threats to livestock breeding activities:

"In our area, the wolf is most important. The most competent, the most predatory, is the wolf. He is of no use, he is very harmful. He eats livestock if we don't put it in the barn" (Shepherd from Ak-Terek, KG: 05/2004)

The impact is enhanced because the general economic situation of the country is pushing people to poverty:

"They are harmful to people. It is a time of destitution and they eat the foal of one person, the sheep of another one, and that's it, it is very hard. People go to the market all the day to earn five som (ca. 0.12 USD)." (Shepherd from Ača-Kajyndy, KG: 03/2004)

Therefore, when Kyrgyz shepherds recall the Soviet time, they point out that the wolf "problem" was better managed at that time: "At that time, hunters tried to reduce [the wolves] whereas now there is no help from the State for that" (Hunter from At-Bašy, KG: 11/2005). Now, "there is no one from the hunting inspectorate hunting wolves like before. There is no hunter hunting wolves with traps. There are no hunters like before. They come and they say they belong to the hunting inspectorate and that's it, they don't do anything" (Shepherd from Kara-Saz, KG: 07/2003). Not only do the official hunters not hunt wolves, but the shepherds can't have a rifle anymore and so can't scare or kill attacking wolves. During the Soviet period all shepherds had a rifle, although only official hunters could hunt wolves, now everybody can hunt the wolf but very few shepherds have a license for a rifle. Moreover, hunters with licenses don't always have enough money to buy bullets:

“There is no help from the State anymore. Hunting inspectors don't have rifles, they don't have bullets, people don't have means, they don't have bullets, and that's why [the wolves] are coming closer." (Shepherd from Ača-Kajyndy, KG: 11/2005)

In addition to hunting activities, the overall presence of armed shepherds in the landscape was perceived as ensuring that wolves had to withdraw back into areas with less human activities. Indeed, during the soviet era the human presence in the landscape was more important. It was possible for livestock breeders to graze their flock in high valleys (called syrt in Kyrgyz) and stay there during the winter thanks to wellmaintained infrastructure and provisioning with helicopters. As it is no longer possible, these high valleys are no longer occupied and generally, livestock breeders are going to summer pastures closer to villages because it is less costly (Jacquesson 2004, Crewett 2012). To some extent, it is now humans who have to withdraw back into areas close to their village and wolves which are now coming down close to villages:

"During the Kolkhoz, there were 52,000 sheep. They were on summer pastures, at the mountains' foothills, whereas now there is nothing, all the livestock is in the 
village and there is not much livestock, so of course [the wolves] come down..." (shepherd from Terek-Suu, KG: 11/2005)

"Now, [the wolves] have adapted to these shrubs whereas before, near these shrubs, there were people, the Kolkhoz's livestock, and people were shooting with the rifle, whereas now [the wolves] are free, they are installed among these shrubs." (shepherd from Žer-Uj, KG: 12/2005)

If Kyrgyz livestock breeders point to the impact that the transition process had on the wolves' population and behaviour and in turn the strong impacts wolves have on their activities, they nevertheless concede that there were many attacks during the Soviet time as well, but as it was Kolkhoz or Sovkhoz livestock, and not their own, it was therefore perceived as being less problematic:

"During the Soviet Era, as they were a lot of livestock at the Sovkhoz, at the Kolkhoz, we weren't feeling that much. [Wolves] were eating, but the shepherds were paying that, without informing people. And then we started to feel it after the fall of the Soviet, when they started attacking private livestock." (shepherd from AkTerek, KG: 05/2004)

"Before, there used to be 30,000 to 100,000 sheep in the Kolkhoz, and wolves were a lot of nuisance. Now the wolf eats only one cow, only one foal from people, and it is difficult for them." (shepherd from Tört-Kül, KG: 04/2004)

Thus, each attack on livestock has a more serious impact on their lives than before in terms of both personal economy and perception. In addition they have the feeling they can't effectively control wolves anymore:

“That's it. We don't manage to control them. At the time when I was shepherd, one could only see wolves with binoculars. Now they go very unhurriedly, they stop, they watch you. It is when you don't have rifle with you. Now there are no rifles and they know that." (shepherd from Ača-Kajyndy, KG: 03/2004)

As a consequence, wolves are now reported to approach villages and attack livestock in the immediate surroundings:

"Otherwise, now they are too close to the villages, they are around At-Bašy and they eat livestock. They cause many troubles to livestock." (Hunter from At-Bašy, KG: 11/2005)

Thus, it appears that rapid social changes in the context of the Kyrgyz transition to the market economy has had a clear impact on human - wolf relationships since it has made livestock breeders more vulnerable to wolf attacks and more prone to be highly affected by these attacks since each domestic animal is economically more valuable than before in this difficult period.

As a consequence, wolves are perceived as a main threat to livestock breeding and thus to most villagers who generally have a few livestock. Despite this situation, many Kyrgyz villagers still have a clear view that wolves shouldn't be eradicated since predators belong to nature and are regarded as having a sanitary role: 
"It is good to have predators. They are nature's beauty so why eradicate them? It is good when they exist. It is good for children who come after and in some places, they have been eliminated, like tigers. Tigers were numerous close to the lake, in Tüp. Now there is no tiger anymore." (retired hunter from Tört-Kül, KG: 04/2004)

"No, there is just a need to decrease the quantity [of wolves] because they eat sick animals and carrion that remains on the fields." (shepherd/hunter from Ača-Kajyndy, KG: 03/2004)

However, this view on the ecological role of the wolf was contested by some:

"Yes, [the wolves] have to be eradicated. All of them! What utility do they have? It is said they are cleaning the fields but to clean the fields we can take foxes, vultures and raven, they eat carrion. I never heard that wolves eat carrion. They only eat livestock. They eat livestock and make carrion, and the rest is eaten by vultures." (shepherd from Žer-Uj, KG: 04/2004)

And furthermore, the wolf impact on livestock is regarded as being hard to bear considering the economic difficulties:

"In these times, [wolves] are an animal we have to eliminate, if possible. Now people don't have many livestock like before." (shepherd from Tört-Kül, KG: 04/2004)

"Right now we don't need wolves. They don't have any utility. [...] They eat foals, they eat livestock without sickness. It is not a sanitary animal. Wolves eat the cow, the calf from a poor man. See what losses it brings!" (shepherd, Bel Tam 04/2004)

As a consequence, the wolf is even seen as threatening the Kyrgyz way of life:

"Outside, yaks are eaten by wolves. So we have to keep them in enclosures, like sheep, like horses. So you see neither horses, nor yaks, nor cows outside. So if we don't eliminate the wolves, what do we do with them? The State could give means. If not where are we going?" (shepherd from Korgondu-Bulak, KG: 12/2005)

\section{Wolves as an additional threat to a highly weakened activity in Macedonia}

The situation in Macedonia appears to be different to the Kyrgyz one. Despite the fact that livestock breeding remains a relatively important economic activity in the country, accounting for $24 \%$ of the total agricultural output in the period 1995-2007 (Dimitrievski and Ericson 2010), livestock breeders are not numerous in the country and the mean size of the owned flocks was generally bigger, at least in the Shara Mountains, than in Kyrgyzstan. Livestock breeding and especially sheep breeding appears to be a more commercial (rather than subsistence) activity in northwestern Macedonia, especially accounting for the fact that it is focused on cheese and lamb production in a highly seasonal manner, while in Kyrgyzstan there is no production of sheep cheese, and mutton and/or lamb meat is consumed year round.

In this situation, sheep are not the main capital for most Macedonian villagers, but rather the object of commercial activity for a few professional livestock 
breeders, at least in the investigated regions. Looking at the results of our investigations, it thus appeared that livestock breeders are mainly complaining about the difficulties inherent to economic activities linked with the transition process and its impact on livestock breeding.

Their first complaint is often about the lack of markets or access to markets. There is a general view that it was better before the collapse of Yugoslavia, when the State bought the cheese and the meat, and "public enterprises were also buying the wool" (shepherd from Pojarane, MK: 05/2008). Not only "were they coming to take the lambs on site" but "if one needed fodder, they could take from this firm" (shepherd from Dobri Dol, MK: 10/2007), and "the State was putting fertilizer on mountain pastures. We were paid to work on mountain pastures, even to mow in some places" (shepherd from Dobri Dol, MK: 11/2007). But "Now there is nothing, no activities" (idem). Not only does the State no longer ensure the market for sheep breeders' products, but also the domestic consumption of lamb and mutton in Macedonia has decreased. It went from $10.1 \mathrm{~kg}$ in 1995 to $3.3 \mathrm{~kg}$ per household in 2007, mainly because of the increased price as a consequence of decreasing sheep production and increased exports (Dimitrievski and Ericson 2010). The domestic consumption of sheep milk and cheese in the country also decreased from 15,643 to 11,291 tons in the same period (idem). Despite the export of lamb and mutton and the increased producer prices, sheep production doesn't cover the large expenses linked with extensive sheep breeding. It is especially important in the northwestern mountainous regions where livestock breeders are notably complaining about the lack of infrastructure to access their high pasture. In several cases the trail going to the summer pasture is only accessible using horses, making it impossible for them to go back home every day and/or to easily transport materials and to bring back milk or cheese.

According to livestock breeders, the market for lamb meat is not stable and exposes livestock breeders to economic risks when they don't manage to sell their lamb quickly. Nobody is interested in buying old lambs. In addition, the expenses are significant and the prices are growing. There is a need for labour to graze and milk sheep and also for additional food like hay and forage in winter in order to be able to produce lambs for the New Year, when their price is higher. Even if they generally manage to produce their own hay, they have to buy supplementary fodder, the price of which has strongly increased: "In previous years, we fed them with fodder like maize, barley, and compound feed, but now, the prices of fodder are quite high" (shepherd from Šipkovica, MK: 11/2007). Therefore, some livestock breeders can't feed them with fodder anymore and then have seen their production decrease, entering a vicious circle potentially driving them to bankruptcy. As a striking consequence of this catastrophic economic situation, most livestock breeders can't invest in or develop their activity, as this man told us:

"But if we would have more sheep, we would have more expenses! In this situation, it would be worse" (shepherd from Dobri Dol, MK: 10/2007)

The situation in Macedonia almost appears as the reverse of the Kyrgyz one. It is difficult for Macedonian livestock breeders to maintain their activity as an economically efficient one and increasing the size of their flock wouldn't help. 
In this tight economic context, any additional cost is an additional weight that can't be tolerated. The wolf is considered as one of these additional costs and doesn't enjoy a positive image among hunters and livestock breeders. Indeed, interactions with wolves are mainly linked to livestock, and shepherds encounter wolves more frequently than hunters (Lescureux and Linnell 2010). As this shepherd explains: "Yes, as we are living in the summer pasture, we often see them, we are living with them!" (Shepherd from Lomincë, MK: 10/2007). For the western part of Macedonia, an interview survey among villagers conducted during 2006 reports 566 attacks on livestock from wolves (Keçi et al. 2008). Not only are wolves considered as harmful for livestock, but this image is reinforced by the fact they can kill multiple sheep in each attack:

“... and the wolf too, if he takes a sheep, it doesn't mean anything, because he also has to live, but when he comes into the place where they are [enclosed], he doesn't take only one, he kills them all, all the ones he find... he cleans up. We had a case here when he killed 70 in one night!" (Hunter from Žurževice, MK: 10/2007)

Even if very few livestock breeders experience that type of surplus killing, the bad reputation of the wolf is widespread and gave rise to this idiom present in Albania and Macedonia claiming that "the wolf will kill 99 sheep and die at the hundredth" (See also Elsie 2001).

In addition to the direct costs linked with attacks on sheep, wolves have an indirect cost through the necessity for livestock breeders to keep livestock guarding dogs:

"[It is better] not having them [the wolves]! Because of the wolves, we feed seven to eight dogs. It is only because of them [the wolves] that we keep dogs. Without dogs we can't go on" (shepherd from Toplica, MK: 10/2007)

Indeed, even if only fed with maize flour or old bread mixed with whey, there is a cost to maintaining livestock guarding dogs (around $1 €$ per dog per day), especially when they often have between 5 or more dogs per flock. Livestock breeders generally consider they would keep dogs even in the absence of wolves, for example to protect against theft, but they would then just keep one or two.

Despite wolves being harmful for livestock and costly for livestock breeders, they don't appear as the major threat for livestock breeding activities. As this sheep breeder remarked:

"No, problems with wild animals, it can be fixed. You know how to fix it. You need to pay more attention, you need more work, less sleep and you manage that way. It is the smallest problem." (Shepherd from Dobri Dol, MK: 10/2007)

However, the economic reasons are not the only ones pushing livestock breeders to have a negative perception of wolves.

\section{Wolves as a symbol of the loss of control over nature in Macedonia}

Indeed, the transition process is not just affecting livestock breeders economically. The ongoing rural abandonment process and the crisis in livestock breeding are also affecting the landscape around the villages as well as the social structures in the villages 
and in the countryside. Therefore, the livestock breeders' perceptions of their social and natural environment are clearly affected and also their feelings concerning the future of their activity. Thus, for people who are traditionally livestock breeders and who have known the period when sheep breeding was flourishing, it is a traumatic experience to see this activity disappearing, since it is not only an economic activity but also a part of their traditions and their identity:

"Sheep are nowhere now. Investment is nowhere. We used to have the slaughterhouse in Gostivar and there we brought the wool, the cheese, the lambs [...]. Now there is nothing, neither slaughterhouse, nor anything else. We, for example, have had sheep from our ancestors' times and now there is nothing." (shepherd from Vrapčište, MK: 11/2007)

Livestock breeding is not the only activity disappearing from the villages. All the study villages from the Shara Mountains were surrounded by fields and orchards which are now mostly abandoned. As this livestock breeder said:

"Everything natural from which we were obtaining our bread in Kalište, it is abandoned now [...], I don't know how it is in France or in the West, I don't know there, but in this region, these people are disregarding the cultivated fields... the ground, the fields have been left abandoned. The government is not present here, why stay?" (idem)

As a consequence, there is a feeling that the surroundings of the villages are becoming wild:

"There are more juniper trees, more bushes, everything becomes wilder, even the pastures. And the fields became wilder. We have 640ha [of fields around the village], everything became pasture. We are using more fields than alpine pastures, because fields are also covered with junipers. Because we don't work in the fields, we don't work anything there and that's why." (shepherd from Vešala, MK: 11/2007)

Moreover, livestock breeders feel particularly isolated and unable to arouse interest from the government, the politicians, or society in general. Some of them are desperate about this situation: "Now, nobody is asking us, nobody is even looking at us" (shepherd from Pojarane, MK: 05/2008) and in general they feel there is a lack of recognition of the value of livestock breeding activities:

"Another important thing is that those who decide to do that job [shepherds] are unfortunately not well paid. They are not valued. [...] Here, shepherds are considered as one of the lower class, but it is a job like any other, and it deserves to be well paid." (shepherd from Galičnik, MK: 05/2008)

Thus, pastures are suffering shrub encroachment; fields are becoming pastures and the former system of order is being disrupted. The situation is very similar to what Höchtl et al. observed in the southwestern Alps:

"Many people felt wronged by politicians and are very unhappy about this situation.

The decreasing usability and accessibility of the landscape leads to a loss of historical 
experience, cultural knowledge and local identity; in short, the land is increasingly losing its value as a "homeland"." (Höchtl et al. 2005)

As a consequence, there is a complete lack of confidence in the future:

"We do this job because we don't have any other choice. If I want to sell the sheep, nobody would buy them, and I can't change. It is difficult even for the future... if things continue in that state as until now, I have no confidence about the future." (shepherd from Zajas, MK: 05/2008)

Thus, most livestock breeders don't want their children to follow their path: "I have children of 10 years old and I tell them to study, to go to school, and not to take that job [of livestock breeder]" (shepherd from Šipkovica, MK: 11/2007), which is not very surprising when they have lost interest and confidence in themselves and their job:

"Well, [this] job doesn't really please me, but I don't know what else to do, because we don't have enough profit, we pay the fodder, we pay the employees, we pay this, we pay that, and then there is no market for our product..." (shepherd from Vrapčište, MK: 11/2007)

Therefore, many livestock breeders have the feeling that their activity is coming to an end, and that in this situation, it is an unsustainable activity apart from the biggest and richest livestock owners having access to subsidies and to the market who can survive.

In this situation of rural areas becoming wilder and more and more hostile for human activities, wolves appear as a wild animal particularly difficult to control and symbolise the intrusion of the wild into the domestic. Indeed, these animals often come to take several sheep and their damage can be relatively important at an individual or regional level. In addition to livestock, wolves often kill hunting dogs and they are also blamed for damage to populations of game animals.

As a result of their perceived damage to wild and domestic animals, and their harmfulness to nature in general, wolves are described as unprofitable monsters (Lescureux and Linnell 2010). Even if wolf hunting is authorized and encouraged, wolves are not easy to hunt as this livestock breeder explains: "I agree to eliminate the wolves, but where to find them? They are masters (ustah in Turk), and the wolves are harmful." (Livestock breeder from Vrapčiste, MK: 11/2007). The difficulties inherent to wolf hunting in steep, forested habitats hinders the ability of humans to react to wolf attacks and thus weakens the reciprocity of human - wolf relationships (cf. Lescureux and Linnell 2010).

If wolves are not the main threat, they are nonetheless an additional threat to a declining activity which is already burdened with unsustainable costs. Their repeated and fatal intrusions into the domestic space create the impression of an animal that is disrespectful of borders and norms (cf. Knight 2000). Therefore they reinforce the fuzziness of the wild - domestic border in an ongoing process of reforestation and shrub encroachment. Harmful for livestock breeders, the wolf also appears as a symbol of land degradation and rural abandonment. As a consequence, a large majority of the livestock breeders we interviewed were in favour of their complete eradication in the 
country, since they don't get any use of them and the place would be quieter without them:

"It is necessary to eliminate them all, to hunt them all, because we don't get any use of them, we don't get anything from them. They are only doing damages, they don't give anything. They can only destroy." (shepherd from Vešala, MK: 11/2007)

"But, if we could eradicate them [the wolves], good for us! Then we would be freer with sheep!" (shepherd from Toplica, MK: 10/2007)

\section{Conclusions}

The transition process has clearly affected both livestock breeding and hunting practices and therefore has had an influence on the frames of human - wolf relationships in these two countries. Moreover, beyond the direct impact, the transition process has generated different socio-economic and environmental contexts in which the place of the wolf has changed when compared to the previous periods under communist control. It therefore appears that changes in livestock breeding and hunting activities brought about by the post-communist transitions have in turn had an impact on human - wolf relationships. In order to understand their impact on the human perceptions of wolves, we had to place all those changes in their specific social and economic context.

In Kyrgyzstan, livestock breeding is one of the main economic activities, and is well regarded. Flocks are a real capital for rural people. In their view of the world, inherited from their shamanistic origins, there are no strong borders between the human world and the animal world, and wolves are considered as intelligent, conscious and even useful animals, removing carrion and killing sick ungulates. The wolf is thus an alter ego engaged in reciprocal relationships with humans (Lescureux 2006, 2007). However, the lack of control over wolves which now occurs is viewed as a loss of reciprocity and a break-down in the balance of the human - wolf relationship, all the more so as livestock breeders are also often hunters. Finally, wolves are no longer perceived as a respectable enemy they have to regulate, but more and more as an invader, preventing the increase of a herder's capital, and even threatening the future of pastoralism and economy in the country:

The situation in Macedonia is different. Sheep are not the main capital, and due to the lack of outlets for cheese and lambs, livestock breeders tend to decrease the size of their flocks to maximize the profit, or at least minimise costs. Moreover, extensive herding of sheep is a marginal activity in the country, and livestock breeders have the feeling they are marginalized and not a concern of the state. While bears are viewed as a kind of alter-ego, wolves have a very different image (Lescureux and Linnell 2010, Lescureux et al. 2011). They are perceived as bloodthirsty and pest animals, destroying livestock, hunting dogs and game animals. In the difficult economic and social context, wolves are not perceived as the main threat to rural life, but are regarded as an additional threat, which symbolizes their loss of control over nature, which is mainly linked to rural abandonment, and therefore have to be eliminated, as wolves have absolutely no usefulness for them.

In both countries contemporary perceptions of wolves don't appear to be a result of the persistence of negative beliefs, but more as a dynamic phenomenon linked with the 
current socio-economic situations, and also linked with the perceived ability of wolves to change their behaviour. Not only were our informants' perceptions of the wolf changing through time but they also had the perception that wolves are changing along with the wolf - human relationship. Therefore, the interactive properties of large carnivores and their possible impact on livestock breeding activities have to be taken into account when evaluating the impact of political and economic transition on pastoralist activities.

The underlying cultural context is also very important however, notably concerning the way people perceive the respective place - and role - of humans and animals in the environment. This question is notably linked with perceived borders between wild and domestic, a border which appears to be very dynamic at the landscape level. Indeed, in both countries we observed that humans have had to withdraw back from parts of the landscape that they were previously utilising (high valleys in Kyrgyzstan and shrubby pastures in Macedonia). At the same time wolves are coming back into these areas and the combination of these two phenomena makes the wolf a symbol of land abandonment and - in the case of Macedonia - rural depopulation.

Therefore, from the point of view of wolf conservation, it is likewise important to view their status and perception by local people within 1) a wider social economic context which is highly dynamic over time (Walker 2005), but also 2) a wider ecological context, taking into account the dynamic process occurring at the landscape level.

It also appears that pastoralism is linked with hunting and wildlife management and takes place in a broader socio-economic and political context prone to rapid changes. Therefore the understanding of pastoralists' conflicts with wildlife requires placing these conflicts into a system of relationships including different actors, both humans and non-humans, who can potentially influence or be affected by these conflicts. This type of analyse requires multidisciplinary efforts in order to combine findings from ecology and the social sciences.

Finally, the challenge for pastoralists is to maintain their activity facing these rapid changes. Despite the often divergent point of view on the topic of large carnivores, pastoralists and wildlife conservationists often are natural allies (Niamir-Fuller et al. 2012), although it is a challenge for both of them to find a sustainable coexistence between pastoralist activities and large carnivore presence.

Competing interests

The authors declare they have no competing interests.

\section{Authors' contributions}

NL participated in the conception and design of the research, acquisition, analysis and interpretation of data for both countries. JL was the project leader for Macedonia and participated in conception and design of research in this country. Both NL and $J$ have been involved in drafting the manuscript and revising it and have given their final approval of the version to be published.

Authors' information

Nicolas Lescureux is an ethno-ecologist who has conducted research on conflicts between livestock breeders and large carnivores in different countries (France, Kyrgyzstan, Macedonia, Bulgaria, and Poland). His main focus is the way by which carnivores' behaviour and ecology can influence human local knowledge, know-how and perceptions. John Linnell is an ecologist by training working on a range of inter-disciplinary approaches to foster wildlife conservation and reduce human-wildlife conflicts.

\section{Acknowledgements}

The field work in KG was funded by the Muséum National d'Histoire Naturelle (Paris). The field work in Macedonia has been funded by successive grants from the Fyssen Foundation, the Research Council of Norway and by an IntraEuropean Fellowship granted to NL from the EU's Marie Curie scheme. We would like to thank Nuraly Turganbaev from Kirghiz national University for his help in the field in Kyrgyzstan, Mustafa Sabit, Gjorge Ivanov, Dime Melovski, and Aleksandar Stojanov from Macedonian Ecological Society for their help in the field in Macedonia. We are also grateful to the two anonymous reviewers for their corrections and comments, which greatly helped us to improve the manuscript. 
Received: 13 November 2012 Accepted: 23 January 2013

Published: 22 February 2013

\section{References}

Alleau, J. 2010. Une histoire du loup à l'époque moderne. Méthodes, sources et perspectives. In Repenser le sauvage grâce au retour du loup. Les sciences humaines interpellées, ed. J-M Moriceau and P Madeline, 23-39. Caen: Presses universitaires de Caen \& MRSH.

Anderson, K, and R Pomfret. 2000. Living standards during transition to a market economy: the Kyrgyz Republic in 1993 and 1996. Journal of Comparative Economics 28: 502-523.

Bangs, EE, SH Fritts, JA Fontaine, DW Smith, KM Murphy, CM Mack, and CC Niemeyer. 1998. Status of gray wolf restoration in Montana, Idaho, and Wyoming. Wildlife Society Bulletin 26: 785-798.

Bibikov, DI. 1973. The Wolf in the USSR. In First Working Meeting of Wolf Specialists and of the First International Conference on Conservation of the Wolf, ed. HD Pimlott. Morges, Switzerland: International Union for Conservation of Nature and Natural Resources.

Bibikov, DI. 1980. Wolves in the USSR. Natural History 89: 58-63.

Bibikov, DI, NG Ovsyannikov, and AN Filimonov. 1983. The status and management of the wolf population in the USSR. Acta Zoologica Fennica 174: 269-271.

Bobbé, S. 1993a. Hors statut, point de salut. Ours et loups en Espagne. Etudes Rurales 129-130: 59-72.

Bobbé, S. 1993b. Ours, loup, chien errant en Espagne. Des couples dans le bestiaire. In Des bêtes et des hommes. Le rapport à l'animal, un jeu sur la distance, ed. B Lizet and GR Giordani, 211-226. Paris: édition du comité des travaux historiques et scientifiques.

Bobbé, S. 2003. Polémique autour d'un projet de zonage, appliqué à la gestion des loups dans l'arc alpin français. Espaces et sociétés 110-111: 111-128.

Boitani, L. 1992. Wolf research and conservation in Italy. Biological Conservation 61: 125-132.

Boitani, L. 1995. Ecological and cultural diversities in the evolution of wolf-human relationships. In Ecology and conservation of wolves in a changing world, ed. LN Carbyn, SH Fritts, and DR Seip, 3-11. Edmonton, Alberta: Canadian Circumpolar Institute.

Boitani, L. 2003. Wolf conservation and recovery. In Wolves: behavior, ecology, and conservation, ed. LD Mech and L Boitani, 317-344. Chicago: The University of Chicago Press.

Boyd, ML. 1987. The performance of private and cooperative socialist organization: postwar Yugoslav agriculture. The Review of Economics and Statistics 69: 205-214.

Breitenmoser, U. 1998. Large predators in the Alps: the fall and rise of man's competitors. Biological Conservation 83: 279-289.

Brox, O. 2000. Schismogenesis in the wilderness: the reintroduction of predators in Norwegian forests. Ethnos 65: 387-404.

Brunois, F. 2005a. Man or animal: who copies who? Interspecific empathy and imitation among the Kasua of New Guinea. In Animal Names, ed. A Minelli, G Ortalli, and G Sanga, 369-381. Venezia: Istituto Veneto di Scienze Lettere ed Arti.

Brunois, F. 2005b. Pour une approche interactive des savoirs locaux : l'ethno-éthologie. Journal de la Société des Océanistes 120-121: 31-40.

Ciucci, P, L Boitani, F Francisci, and G Andreoli. 1997. Home range, activity and movements of a wolf pack in Central Italy. Journal of Zoology, London 243: 803-819.

Clark, TW, AP Curlee, and RP Reading. 1996a. Crafting effective solution to the large carnivore conservation problem. Conservation Biology 10: 940-948.

Clark, TW, PC Paquet, and AP Curlee. 1996b. Special section: large carnivore conservation in the Rocky Mountains of the United States and Canada. Introduction. Conservation Biology 10: 936-939.

Coleman, JT. 2004. Vicious: wolves and men in America. New Haven: Yale University Press.

Comincini, M, A Oriani, C Morbioli, R Castiglioni, and A Martinoli. 2002. L'uomo e la "bestia antropofaga". Storia del lupo nell'Italia settentrionale dal XV al XIX secolo. Milan: Unicopli.

Crewett, W. 2012. Improving the Sustainability of Pasture Use in Kyrgyzstan. Mountain Research and Development 32: $267-274$.

Dear, C, H Weyerhaeuser, H Hurni, SW von Dach, and A Zimmermann. 2012. Special issue: Central Asian mountain societies in transition. Mountain Research and Development 32: 265-266.

Descola, P. 2005. Par-delà nature et culture. Paris: Gallimard.

Descola, P, and G Pálsson. 1996. Nature and Society. Anthropological perspectives. London: Routledge.

Dimitrievski, D, and T Ericson. 2010. Sector Study - Macedonian Agriculture in the period 1995-2007.: University Ss Cyril and Methodius \& Swedish University of Agricultural Sciences.

Doré, A. 2010. L'histoire dans les méandres des publics : quand les "méchants loups" ressurgissent du passé. In Repenser le sauvage grâce au retour du loup. Les sciences humaines interpellées, ed. J-M Moriceau and P Madeline, 75-89. Caen: Presses Universitaires de Caen.

Elsie, R (ed.). 2001. A dictionary of Albanian religion, mythology, and folk culture. New York: New York University Press.

Falcucci, A, L Maiorano, and L Boitani. 2007. Changes in land-use/land-cover patterns in Italy and their implication for biodiversity conservation. Landscape Ecology 22: 617-631.

FAOSTAT. 2012. Food and Agriculture Organization. http://faostat3.fao.org/home/index.html\#HOME. Accessed 01 June 2012.

Fritts, SH, EE Bangs, JA Fontaine, MR Johnson, MK Phillips, ED Koch, and JR Gunson. 1997. Planning and implementing a reintroduction of wolves to Yellowstone National Park and central Idaho. Restoration Ecology 5: 7-27.

Fritts, SH, RO Stephenson, RD Hayes, and L Boitani. 2003. Wolves and humans. In Wolves: behavior, ecology, and conservation, ed. LD Mech and L Boitani, 289-316. Chicago: The University of Chicago Press. 
Hadjigeorgiou, I. 2011. Past, present and future of pastoralism in Greece. Pastoralism: Research, Policy and Practice 1: 24. 10.1186/2041-7136-1-24.

Hadživuković, S. 1989. Population growth and economic development: a case study of Yugoslavia. Journal of Population Economics 2: 225-234.

Haraway, D. 2003. The Companion Species Manifesto. Dogs, People, and Significant Otherness. Chicago: Prickly Paradigm Press.

Höchtl, F, S Lehringer, and W Konold. 2005. "Wilderness": what it means when it becomes reality - a case study from the southwestern Alps. Landscape and Urban Planning 70: 85-95.

Huntington, HP. 2000. Using traditional ecological knowledge in science: methods and applications. Ecological Applications 10: 1270-1274.

Ingold, T. 1996. Hunting and gathering as ways of perceiving the environment. In Redefining nature: ecology, culture and domestication, ed. R Ellen and K Fukui, 117-154. Oxford: Berg.

Ingold, T. 2000. From trust to domination. An alternative history of human-animal relations. In The perception of environment. Essays on livelihood, dwelling and skill, ed. T Ingold, 61-76. London and New York: Routledge.

Ivanov, G, A Stojanov, D Melovski, V Avukatov, E Keçi, A Trajçe, S Shumka, G Schwaderer, A Spangenberg, JDC Linnell, M von Arx, and U Breitenmoser. 2008. Conservation status of the critically endangered balkan lynx in Albania and Macedonia. In Proceedings of the III congress of ecologists of the Republic of Macedonia with international participation, ed. MES, 249-256. Skopje (Macedonia): Macedonian Ecological Society.

Jacquesson, S. 2004. Au coeur du Tian Chan : histoire et devenir de la transhumance au Kirghizstan. Cahiers d'Asie Centrale 11(12): 203-244.

Kaczensky, P. 1999. Large carnivore predation on livestock in Europe. Ursus 11: 59-72.

Keçi, E, A Trajçe, K Mersini, F Bego, G Ivanov, D Melovski, A Stojanov, U Breitenmoser, M VonArx, G Schwaderer, A Spangenberg, and JDC Linnell. 2008. Conflicts between lynx, other large carnivores, and humans in Macedonia and Albania. In Proceedings of the III congress of ecologists of the Republic of Macedonia with international participation (06-09.10.2007), 257-264. Skopje: MES.

Kellert, SR, M Black, C Reid Rush, and AJ Bath. 1996. Human culture and large carnivore conservation in North America. Conservation Biology 10: 977-990.

Knight, J. 2000. Introduction. In Natural Enemies. People-wildlife conflicts in anthropological perspective, ed. J Knight, 1-36. London: Routledge.

Koshkarev, E. 1994. Poaching in Kyrgyzstan. Cat News, newsletter of the IUCN Cat Specialist Group 21.

Latour, B. 1996. On actor-network theory. A few clarifications plus more than a few complications. Soziale Welt 47: 369-381.

Lescureux, N. 2006. Towards the necessity of a new interactive approach integrating ethnology, ecology and ethology in the study of the relationship between Kirghiz stockbreeders and wolves. Social Science Information 45: 463-478.

Lescureux, N. 2007. Maintenir la réciprocité pour mieux coexister. Ethnographie du récit kirghiz des relations dynamiques entre les hommes et les loups. Paris: Muséum National d'Histoire Naturelle.

Lescureux, N, and JDC Linnell. 2010. Knowledge and perceptions of Macedonian hunters and herders: the influence of species specific ecology of bears, wolves, and lynx. Human Ecology 38: 389-399.

Lescureux, N, JDC Linnell, D Melovski, A Stojanov, G Ivanov, and V Avukatov. 2011. The king of the forest. Local knowledge about European brown bears (Ursus arctos) and implications for its conservation in contemporary Western Macedonia. Conservation and Society 9: 189-201.

Liechti, K. 2012. The meanings of pasture in resource degradation negotiations: evidence from post-socialist rural Kyrgyzstan. Mountain Research and Development 32: 304-312

Linnell, JDC, JE Swenson, and R Andersen. 2001. Predators and people: conservation of large carnivores is possible at high human densities if management policy is favourable. Animal Conservation 4: 345-349.

Linnell, JDC, EJ Solberg, SM Brainerd, O Liberg, H Sand, P Wabakken, and I Kojola. 2003. Is the fear of wolves justified? a fennoscandian perspective. Acta Zoologica Lituanica 13: 34-40.

Linnell, JDC, U Breitenmoser, C Breitenmoser-Würsten, J Odden, and M von Arx. 2009. Recovery of Eurasian lynx in Europe: What part has reintroduction played? In Reintroduction of top-order predators, ed. M Hayward and $\mathrm{M}$ Sommers, 72-91. Oxford: Blackwell Publishing.

Løe, J, and E Røskaft. 2004. Large carnivores and human safety: a review. Ambio 33: 283-288.

Lohr, C, WB Ballard, and AJ Bath. 1996. Attitudes toward gray wolf reintroductions to New Brunswick. Wildlife Society Bulletin 24: 414-420

Lopez, BH. 1978. Of wolves and men. New York: Charles Scribner's.

MacFarlane, N, S Torjesen, and C Wille. 2004. An anomaly in Central Asia? Small Arms in Kyrgyzstan. In Small arms survey 2004 - rights at risk, ed. P Batchelor and K Krause, 309-324. New York: Oxford University Press.

MAFWE. 2003. Country Report on the State of the Animal Genetic Resources in Republic of Macedonia.: Republic of Macedonia Ministry of Agriculture, Forestry and Water Economy.

Mauz, I. 2005. Gens, cornes et crocs. Paris, Grenoble: Inra-Quae.

Mech, LD. 1970. The wolf the ecology and behavior of an endangered species. Minneapolis: University of Minnesota Press.

Mech, LD. 1995. The challenge and opportunity of recovering wolf populations. Conservation Biology 9: 270-278,

Mertens, A, and C Promberger. 2001. Economic aspects of large carnivore-livestock conflicts in Romania. Ursus 12: 173-180.

Ministry of Environment and Physical Planning. 2003. Biodiversity Strategy and Action Plan for the Republic of Macedonia.

Moore, RS. 1994. Metaphors of encroachment: hunting for wolves on a Central Greek Mountain. Anthropological Quarterly 67: 81-88.

Moriceau, J-M. 2007. Histoire du méchant loup. 3000 attaques sur l'homme en France. Paris: Fayard.

Niamir-Fuller, M, C Kerven, R Reid, and E Milner-Gulland. 2012. Co-existence of wildlife and pastoralism on extensive rangelands: competition or compatibility? Pastoralism: Research Policy and Practice

2012: 8. doi:10.1186/2041-7136-2-8. 
Pardini, A, and M Nori. 2011. Agro-silvo-pastoral systems in Italy: integration and diversification. Pastoralism: Research, Policy and Practice 1: 26. doi:10.1186/2041-7136-1-26.

Petkovski, S, D Smith, T Petkovski, and V Sidorovska. 2003. Study on hunting activities in Macedonia: past, present and future: Society for the Investigation and Conservation of Biodiversity and the Sustainable Development of Natural Ecosystems (BIOECO).

Rajpurohit, KS. 1999. Child lifting: wolves in Hazaribagh, India. Ambio 28: 162-166.

Røskaft, E, T Bjerke, BP Kaltenborn, and JDC Linnell. 2003. Patterns of self reported fear towards large carnivores among the Norwegian public. Evolution and Human Behaviour 24: 184-198.

Røskaft, E, B Handel, T Bjerke, and BP Kaltenborn. 2007. Human attitudes towards large carnivores in Norway. Wildlife Biology 13: 172-185.

Salvatori, V, and JDC Linnell. 2005. Report on the conservation status and threats for wolf (Canis lupus) in Europe. Conseil de l'Europe - Council of Europe.. Report T-PVS/Inf (2005) 16.

Servheen, C, S Herrero, and B Peyton (eds.). 1998. Bears. Status Survey and Conservation Action Plan. Switzerland \& Cambridge, UK: IUCN/SSC Bear and Polar Bear Specialist Group, Gland.

Sidorovich, VE, LL Tikhomirova, and B Jędrzejewska. 2003. Wolf Canis lupus numbers, diet and damage to livestock in relation to hunting and ungulate abundance in northeastern Belarus during 1990-2000. Wildlife Biology 9: 103-111.

Skogen, K, I Mauz, and O Krange. 2008. Cry wolfl: narratives of wolf recovery in France and Norway. Rural Sociology 73: $105-133$.

Theuerkauf, J. 2003. Impact of man on wolf behaviour in the Bialowieza Forest. Poland: Technischen Universität München, Munich.

Theuerkauf, J. 2009. What drives wolves: fear or hunger? humans, diet, climate and wolf activity patterns. Ethology 115: 649-657.

Theuerkauf, J, W Jedrzejewski, K Schmidt, and R Gula. 2003a. Spatiotemporal segregation of wolves from humans in the Bialowieza forest (Poland). Journal of Wild life Management 67: 706-716.

Theuerkauf, J, W Jedrzejewski, K Schmidt, H Okarma, I Ruczynski, S Sniezko, and R Gula. 2003b. Daily patterns and duration of wolf activity in the Bialowieza forest, Poland. Journal of Mammalogy 84: 243-253.

Treves, A, and KU Karanth. 2003. Human-carnivore conflict and perspectives on carnivore management worldwide Conservation Biology 17: 1491-1499.

Van Veen, TWS. 1995. The Kyrgyz sheep herders at a crossroad. Pastoral Development Network Series 38: 1-14.

Vilà, C, V Urios, and J Castroviejo. 1995. Observations on the daily activity patterns in the Iberian Wolf. In Ecology and Conservation of Wolves in a Changing World, ed. LN Carbyn, SH Fritts, and DR Seip, 335-340. Alberta: Canadian Circumpolar Institute.

Vyrypajev, VA, and GG Vorobjev. 1983. Volk v Kirgizii. Frunze: llim.

Walker, BL. 2005. The lost wolves of Japan. Seattle: University of Washington Press.

World Bank. 2005. Kyrgyz Republic. Livestock Sector Review: Embracing the New Challenges.: World Bank.

doi:10.1186/2041-7136-3-4

Cite this article as: Lescureux and Linnell: The effect of rapid social changes during

post-communist transition on perceptions of the human - wolf relationships in Macedonia and Kyrgyzstan.

Pastoralism: Research, Policy and Practice 2013 3:4.

\section{Submit your manuscript to a SpringerOpen ${ }^{\circ}$} journal and benefit from:

- Convenient online submission

Rigorous peer review

- Immediate publication on acceptance

- Open access: articles freely available online

- High visibility within the field

- Retaining the copyright to your article

Submit your next manuscript at $\boldsymbol{\nabla}$ springeropen.com 